\title{
Using the Ecosystem Services Concept to Assess Transformation of Agricultural Landscapes in the European Alps
}

\author{
Uta Schirpke $^{1,2}$, Erich Tasser $^{2}\left(\mathbb{D}\right.$, Georg Leitinger ${ }^{1}\left(\mathbb{D}\right.$ and Ulrike Tappeiner ${ }^{1,2, *(\mathbb{C}}$ \\ 1 Department of Ecology, University of Innsbruck, 6020 Innsbruck, Austria; Uta.Schirpke@uibk.ac.at (U.S.); \\ Georg.Leitinger@uibk.ac.at (G.L.) \\ 2 Institute for Alpine Environment, Eurac Research, 39100 Bolzano, Italy; erich.tasser@eurac.edu \\ * Correspondence: ulrike.tappeiner@uibk.ac.at
}

check for updates

Citation: Schirpke, U.; Tasser, E.; Leitinger, G.; Tappeiner, U. Using the Ecosystem Services Concept to Assess Transformation of Agricultural Landscapes in the European Alps. Land 2022, 11, 49. https://doi.org/10.3390/land11010049

Academic Editor: Monika Kopecká

Received: 17 November 2021

Accepted: 28 December 2021

Published: 30 December 2021

Publisher's Note: MDPI stays neutral with regard to jurisdictional claims in published maps and institutional affiliations.

Copyright: (C) 2021 by the authors. Licensee MDPI, Basel, Switzerland. This article is an open access article distributed under the terms and conditions of the Creative Commons Attribution (CC BY) license (https:// creativecommons.org/licenses/by/ $4.0 /)$.

\begin{abstract}
Mountain farming sustains human well-being by providing various ecosystem services (ES). In the last decades, socio-economic developments have led to worldwide changes in land-use/cover (LULC), but the related effects on ES have not been fully explored. This study aimed at assessing the impacts of the transformation of agricultural land on ES in the European Alps. We mapped 19 ES within the agriculturally used areas in the year 2000 and analyzed LULC changes by 2018. We compared eight regions with a similar development, regarding social-ecological characteristics, to outline contrasting trends. Our results indicate that the ES decreased most strongly in regions with a massive abandonment of mountain grassland, while ES in the 'traditional agricultural region' remained the most stable. In regions with an intensification of agriculture, together with urban sprawl, ES had the lowest values. Across all regions, a shift from ES that are typically associated with mountain farming towards forest-related ES occurred, due to forest regrowth. By relating differing trends in ES to social-ecological developments, we can discuss our findings regarding new landscapes and farming systems across the European Alps. Our quantitative and spatially explicit findings provide a valuable basis for policy development, from the regional to the international/EU level, and for adopting sustainable management strategies.
\end{abstract}

Keywords: social-ecological system; mountain region; spatial analysis; land-use change; farming

\section{Introduction}

The IPBES (Intergovernmental Platform on Biodiversity and Ecosystem Services) conceptual framework names three interactions between human societies and the non-human world: nature, nature's benefits to humans, and a good quality of life. To value NCPs (nature's contributions to people; defined here as any positive contribution or benefit, and occasionally negative contributions, losses, or degradations, that humans receive from nature), the concept of ecosystem services (ES) is often used. Since, NCPs are consistent with the original use of the term ES in the Millennium Ecosystem Assessment [1], we define ES as the contributions ecosystems make to human well-being, including the goods and benefits that people subsequently derive from them. The IPBES further reinforces the need for initiatives at the science-society interface, aiming at sustainable futures in the light of global change [2]. Our study applies the ES concept to value the transformation of landscapes in this context, contributing to a possible sustainable adaptation of land-use/cover changes (LULC). Here, we focus on agricultural landscapes, as they are particularly affected by global change, with wide-ranging consequences for society [3-5]. Agricultural ecosystems contribute to a variety of ES, such as food and fodder provision, soil conservation, erosion protection, climate regulation, habitat provision, aesthetics, and recreation [6-8]. In particular, organic or traditional farming systems provide high levels of multiple ES, while conventional farming systems are focused on food production [9-13]. In mountain regions, small-scale farming systems and sustainable management practices have been developed 
over centuries to cope with the challenging topographic and climatic conditions [14]. This has shaped appealing mountain landscapes, which are rich in biodiversity and provide many ES to local people, tourists, and adjacent lowland populations [15-24]. However, institutional and political drivers, socio-economic shifts, urbanization, and technical developments have reduced the competitiveness of these marginal areas and induced a massive abandonment of alpine pastures and meadows in European mountain regions during the last century [25-32]. At the same time, less steep areas in the valley bottoms with a favorable climate and easy access have been intensified, often managed by larger and more specialized farms $[33,34]$. Such changes have led to still ongoing transformations in agricultural landscapes, with implications for biodiversity and manifold ES [22,23,35-37]. For example, the intensification of agricultural land causes a decline in water quality, because of higher nutrient input, and a reduction in pollination, due to the use of pesticides and a habitat loss $[6,38,39]$. In addition to a decline in forage provision, the abandonment of alpine pastures and meadows leads to a loss of many cultural ES. In contrast, the provision of timber and non-wood products, and the regulation of the climate and protection from hazards increase due to forest regrowth $[33,36]$. Hence, previous conditions and past processes not only show an impact on current landscape patterns and functions, but can also determine, to a great extent, future pathways of landscape change [40].

Such developments require the attention of decision-makers and land managers, to foster a sustainable development of mountain regions and maintain high levels of multiple ES provision [41-44]. There is growing evidence that the concept of ES, acknowledging the human benefits obtained from the interaction with ecosystems, provides a valuable basis to support landscape planning and management, in various ways [41,45]. This may include raising the awareness of stakeholders, developing management strategies, and taking decisions [46]. In particular, ES maps can be supportive for identifying developments of ES over space and time $[36,38,47]$. They can be used for revealing synergies and tradeoffs among multiple ES [24,48,49], and consequently, for setting priorities in land-use decisions; for example, how intensive agricultural use maximizes provisioning ES, while reducing other ES [50,51]. Maps can also help to identify the spatial separation between farming activities and consumers, which is responsible for trading agricultural products globally [19,52,53]. On this basis, decision-makers can develop nature-based solutions, such as promoting dietary shifts, to strengthen the consumption of local products.

However, quantitative and spatially explicit information on the impacts from the transformation of agricultural land is often not available [54,55]. One reason is that studies on LULC in agricultural landscapes are often not sufficiently linked to the concept of ES [51]. Although there is an increasing number of studies dealing with ES in mountain regions in general, many studies have not considered changes in ES over time [56] or did not specifically analyze agricultural landscapes [51]. Regarding spatial coverage, most studies concentrated on the local level, e.g., [28,57-59], or, if carried out at regional or national level, largely neglected social-ecological differences within and across regions [21]. Consequently, national or even regional policies fail to consider diverging local developments, which occur due to the high complexity of large mountain ranges, such as the European Alps, that include a high variety of climatic, topographic, socio-cultural, and political conditions [14]. Furthermore, many studies focused on a limited number of ES [60]. Data on ES that are not directly linked to land-use/land-cover (LULC) or that are more difficult to assess (e.g., many cultural ES) are largely lacking. Therefore, ES are still rarely integrated into policies and decision-making [60].

To contribute to a more comprehensive understanding of recent developments in the European Alps, this study was aimed at assessing the impacts of the transformation of agricultural landscapes on 19 ES. By differentiating eight regions with distinct social-ecological characteristics, our findings illustrate contrasting developments in ES and highlight diverse pathways for agricultural landscapes in mountain regions. 


\section{Materials and Methods}

\subsection{Study Area}

The European Alps are the highest mountain chain in Europe and contain a large variety of landscapes, species, and cultures. They count about 14 million inhabitants and stretch over eight different countries, including parts of France, Switzerland, Italy, Austria, Germany, and Slovenia, as well as the countries Liechtenstein and Monaco. The Alps are a hot spot of biodiversity, and the complex topography influences the natural distribution of soil, the typology of land, and habitat variety. About $49 \%$ of the area is covered by forest, followed by agricultural land (27\%), high mountain landscapes with shrubs, natural grasslands and rocks (19\%), artificial surfaces (3.7\%), and water (1.1\%).

Due to the high variety of social-ecological conditions across the Alps, the analyses of this study are based on eight regions with different economic and social structures or environmental situations [61]. These regions were identified by Tappeiner et al. [61] through cluster analysis (Ward method, squared Euclidian distance), based on 21 indicators that reflect the three pillars of sustainability in equal measure (Table S1). The classification refers to data between 2000 and 2008, as well as between 1990 and 2002 for change indicators. An updated classification is currently not available. The eight regions (Figure 1) can be summarized as follows:

- $\quad$ 'Employment hubs' are municipalities to which many employed persons commute daily. They have a good transport infrastructure and offer a good range of jobs in the secondary and tertiary sectors.

- 'Residential municipalities' are typical residential and dormitory municipalities located around major employment hubs. Daily commuting is possible without great loss of time, due to the above-average traffic infrastructure. The residential environment in these municipalities is attractive, and land prices are affordable, which leads to increased urban sprawl.

- 'Important tourist centers' have very well-developed accommodation facilities; the employment situation is better than average in the Alps. Most of them are rural municipalities with largely intact agriculture and an attractive landscape.

- 'Dynamic rural areas' are characterized by a rural location and a dynamic labor market. The employment of women and older persons in particular has improved significantly here, not least due to the positive development of tourism. Agriculture in these areas is largely intact. Of concern, however, is the above-average emigration of employed persons.

- 'Standard Alpine regions' reach average values for the Alps in all aspects. Typical of these are low tourism intensity, a negative commuter balance, and a decline in agriculture. Balanced migration and birth rates, however, prevent excessive overaging in these municipalities.

- 'Traditional agricultural regions' are characterized by a severe over-aging of society, poor traffic infrastructure, and a moderate retreat of, mostly extensive, agriculture from the area. The poor employment situation in these regions is likely to contribute to the fact that the number of abandoned farms is limited. Overall, this results in a rich, traditional landscape.

- $\quad$ 'Rural retreats' are characterized by good traffic infrastructure, which residents use to commute to work while keeping their center of life in the rural hinterland. Agriculture has largely retreated from the area, creating a slightly fragmented and highly diverse landscape.

- 'Forgotten rural areas' are characterized by significant over-aging and a particularly strong abandonment of agriculture. A major reason for this is remoteness and poor traffic infrastructure. The areas show great economic weakness and are threatened by depopulation. 


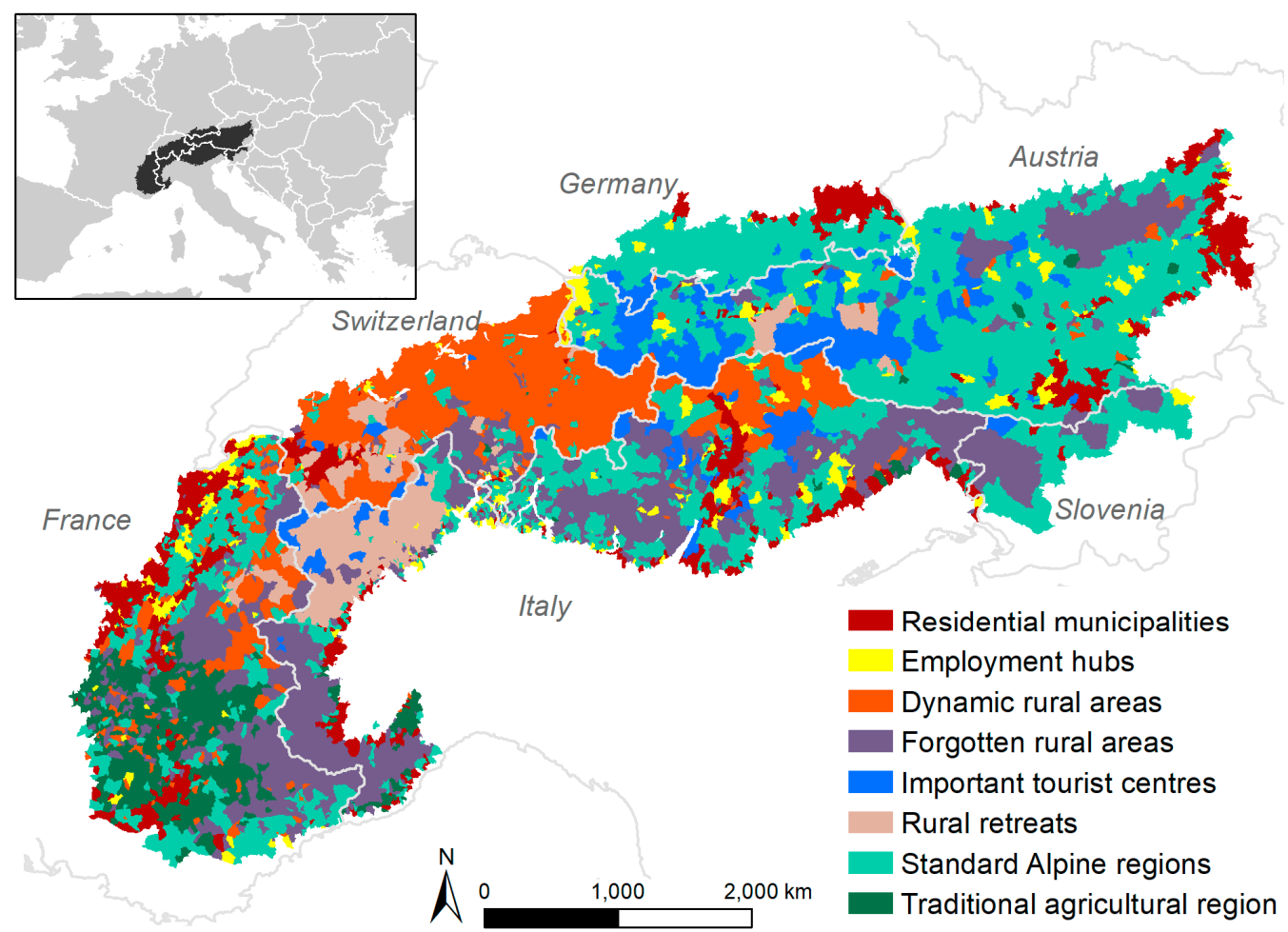

Figure 1. Location of the European Alps in Europe (small map), and the eight social-ecological regions in the study area, as identified by Tappeiner et al. [61] (large map). Authors own elaboration.

\subsection{Analysis Steps}

We analyzed changes in agricultural land between 2000 and 2018 in the European Alps for the eight above described social-ecological regions, based on LULC distribution, and related these developments to 19 ES. The ES mapping and impact analysis in this study comprised the following three steps (Figure 2):

1. Aggregation of LULC types: We used CORINE Land Cover data (CLC) in raster format with a spatial resolution of $100 \times 100 \mathrm{~m}$ for the years 2000 [62] and 2018 [63]. We aggregated the 44 CLC classes to 11 LULC types (Table S2), mainly representing the first and second level of thematic detail, according to the hierarchical nomenclature of CLC $[62,63]$. Based on the LULC distribution in 2000, we selected four agricultural LULC types (crop cultivation, permanent culture, fertilized grassland, unfertilized grassland), which we used to extract the aggregated LULC maps in 2000 and 2018 to the same spatial extent, focusing on agricultural areas.

2. Calculation of ES values: We created ES raster maps by relating the LULC types in 2000 and 2018 to ES values (Table S3). Moreover, we distinguished raster cells with slope < and $\geq 30^{\circ}$ to distinguish flat areas that do not need 'protection from hazards (R1)' due to the presence of steep areas. ES values represent the ES supply, which was weighted by socio-cultural preferences [50]. Tasser et al. [50] and Schirpke et al. [25] derived the ES supply from an extensive literature review on ES-relevant ecosystem processes and functions related to water, soil, plants, animals, microorganisms, agricultural production, and landscape structure. Socio-cultural preferences (from $1=$ low to $5=$ high) were obtained from surveys $[18,64]$. Hence, ES that were more preferred obtained higher final ES values than those ES of lower importance (for details, see Tasser et al. [50]). Final ES values are expressed as a dimensionless index, ranging from 0 to 5, and were used to map ES based on the aggregated LULC types, i.e., each raster cell of a specific LULC type was associated with the respective ES value of Table S3. 
3. Impact analysis: To identify differing trends in LULC and ES across the eight regions with differing social-ecological characteristics, we spatially overlaid the raster maps (aggregated LULC, ES values) with the eight regions (Figure 1). We calculated areaweighted mean values for each region in 2000 and 2018, which were used to map and evaluate changes in LULC and ES values.

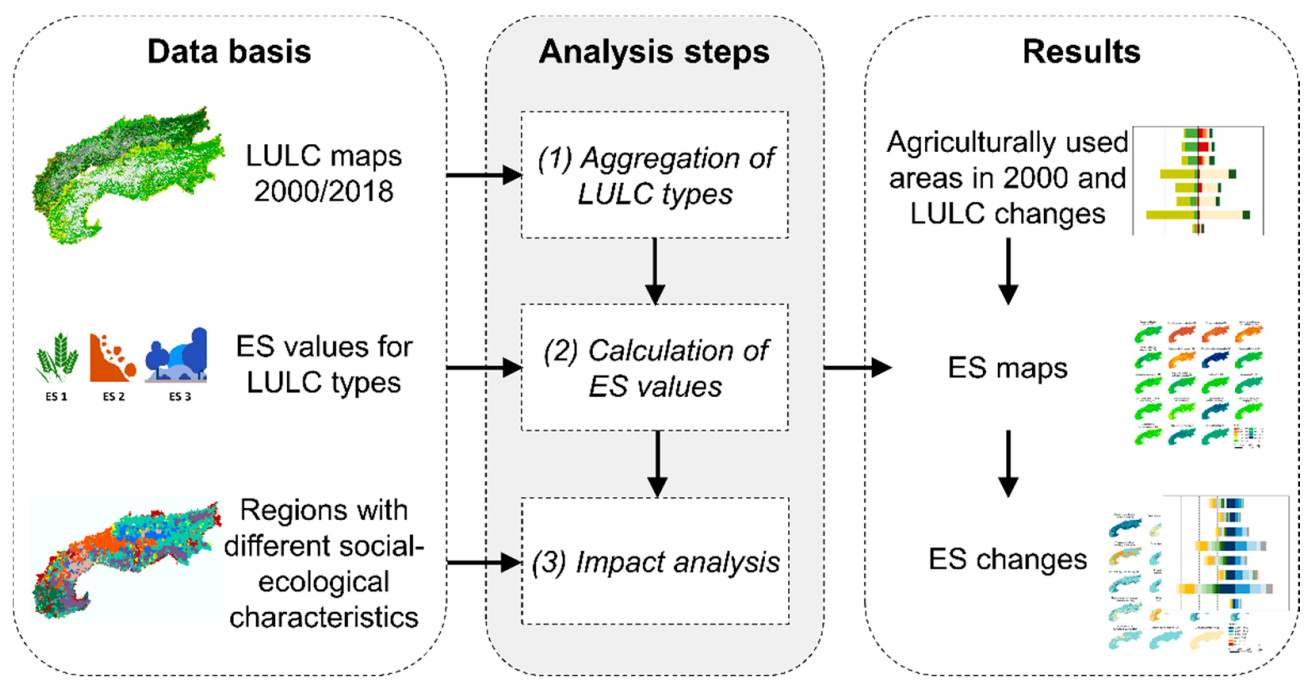

Figure 2. Conceptual steps for examining trends in ES values across different regions with distinct social-ecological characteristics in the European Alps, only considering areas that were agriculturally used in 2000. Authors own elaboration.

\section{Results}

\subsection{LULC Changes}

The composition of agricultural land in 2000 varied across the eight regions (Figure 3). The residential municipalities, employment hubs, the standard Alpine region, and the traditional agricultural region comprised mostly intensively used LULC types, such as crop cultivation, permanent cultures, and fertilized grassland, whereas unfertilized grassland prevailed in the other four regions. LULC changes between 2000 and 2018 generally consisted in the abandonment of fertilized and unfertilized grassland, and in an increase in settlement area, forest, and abandoned grassland. Change rates, however, greatly differed across the eight regions (Figure 3). The smallest changes occurred in the traditional agricultural region, while the largest changes happened in rural retreats and forgotten rural areas. Residential municipalities and employment hubs had the largest increases in settlement areas, while forest increased above average in forgotten rural areas and rural retreats. Agriculturally used grasslands were frequently abandoned, especially in the latter two regions, but also in the tourist centers and in the dynamic rural areas, resulting in forested areas or succession stages towards forest, such as dwarf-shrub habitats and bushland. In addition, crop cultivation and permanent cultures slightly increased around the main settlement regions, mainly in residential municipalities and standard Alpine regions.

\subsection{Changes in ES Values}

Considering only agricultural LULC types (i.e., crop cultivation, permanent culture, fertilized grassland, unfertilized grassland) that were present in 2000, ES values varied across the eight regions (Figures 4 and A1). The lowest ES values occurred in the economically prosperous employment hubs, including the suburbanization region (residential municipalities), mainly due to less ecosystems with high ES supply and below-average values for cultural and regulating ES. In contrast, regions with a high increase in forest or a high share of unfertilized grassland, including alpine pastures and traditional agro-forestry 
systems, had the highest ES values; in particular, wood production (P5), occurrence of mushrooms and wild berries (P4), protection against natural hazards (R1), availability of usable water (R2), preservation of valuable habitats and species (R3, R4, and R5), positive impact on climate (R9), opportunities for leisure activities (C1), aesthetic experiences (C4), and cultural heritage (C5). Regions with a high proportion of intensive agricultural land (i.e., crop cultivation, permanent crops, and fertilized grassland) had lower ES values for regulating and cultural ES.

LULC 2000

$0 \%$

Residential municipalities

Employment hubs

Standard Alpine regions

Forgotten rural areas

Important tourist centres

Dynamic rural areas

Rural retreats

Traditional agricultural region

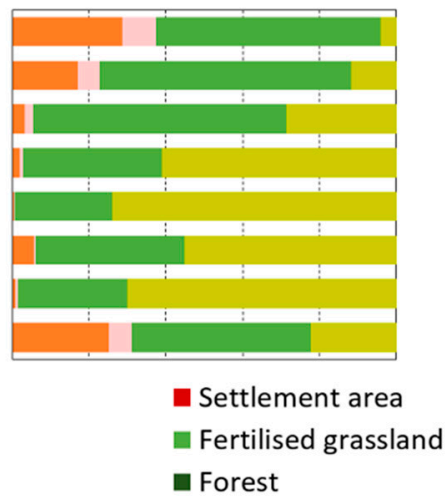

LULC 2018

LULC change 2000-2018

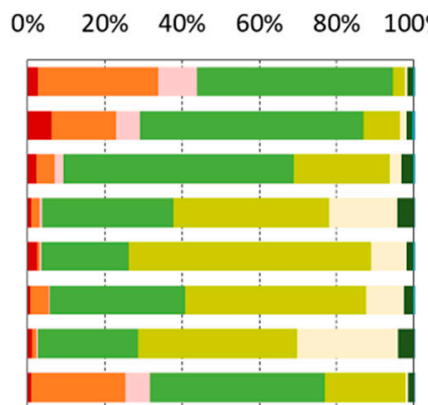

Crop cultivation

- Unfertilised grassland

Wetlands \& water

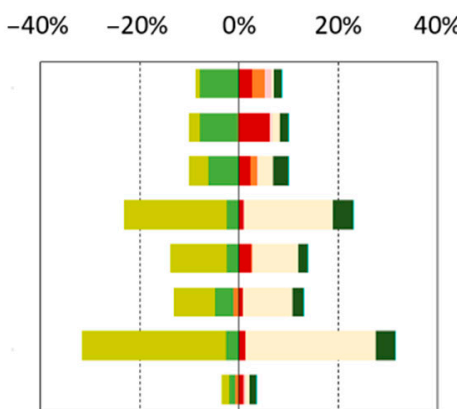

Permanent culture

Abandonded land

Figure 3. LULC distribution across eight social-ecological regions in the European Alps in 2000 (left) and 2018 (center), as well as LULC changes between 2000 and 2018 (right), only referring to the area that was covered in 2000 by agricultural LULC types (i.e., crop cultivation, permanent culture, fertilized grassland, and unfertilized grassland). Wetlands, rivers, lakes are summarized as 'wetlands \& water'. Authors own elaboration.

ES value 2000

ES value 2018

Change in ES value 2000-2018 5060

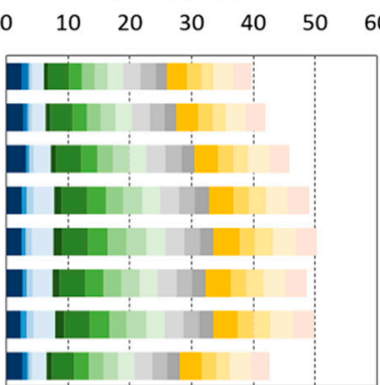
$60-2.0-1.5-1.0-0.5 \quad 0.0 \quad 0.5 \quad 1.0 \quad 1.5$
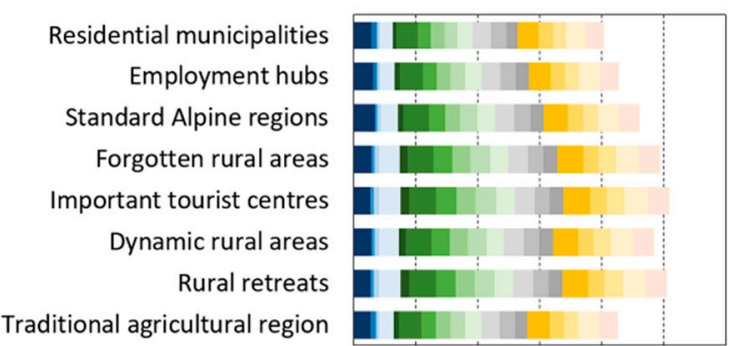

\section{Provisioning ES}

- Pasture and fodder production (P1)

- Agricultural food production (P2)

- Timber production (P3)

Gathering mushrooms and wild berries (P4)

Provision of clean drinking water (P5)

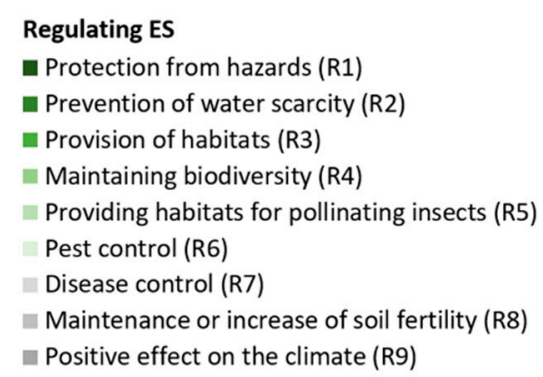

\section{Regulating ES}

- Protection from hazards (R1)

- Prevention of water scarcity (R2)

a Provision of habitats (R3)

Maintaining biodiversity (R4)

Providing habitats for pollinating insects (R5)

Pest control (R6)

Disease control (R7)

Maintenance or increase of soil fertility (R8)

- Positive effect on the climate (R9)

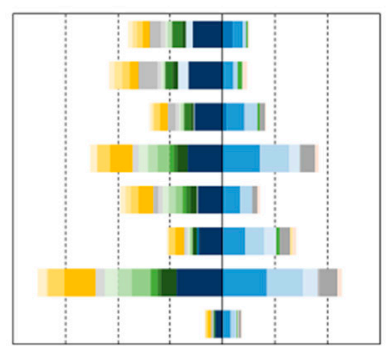

\section{Cultural ES}

Opportunities for leisure activities (C1)

Attractive housing and living space (C2)

Experience of animals \& plants (C3)

Aesthetic inspiration (C4)

Cultural heritage (C5)

Figure 4. ES values in 2000 (left), 2018 (center), and change in ES value between 2000 and 2018 (right). Authors own elaboration.

ES values between 2000 and 2018 mostly declined, especially, regulating and cultural ES, mainly due to LULC changes of agricultural land towards other LULC types, including abandoned land, forest, and settlement areas. On the other hand, provisioning ES increased except for fodder production (P1), but the changes in ES values varied across the eight 
regions (Figures 4 and 5). Corresponding to the small LULC changes, the smallest changes in ES values occurred in the traditional agricultural region. Changes in employment hubs and residential municipalities were also below average, but there was a further decline in provisioning ES, due to the increasing urban sprawl. Rural retreats had a particularly strong decrease in many cultural and regulating ES values, with the exception of the positive effect on the climate (R9), due to an increase of forests and abandoned land (including heathlands, transitional woodlands, and shrub) on former agricultural land; however, provisioning ES also increased above average, apart from fodder production (P1) and agricultural food production (P2). Across all ES, positive trends only prevailed over negative ones in the dynamic rural areas and the traditional agricultural regions. In spatial terms, the greatest changes occurred in the Southern Alps in Italy and Slovenia, and the Western Alps were more affected by changes than the Eastern Alps.
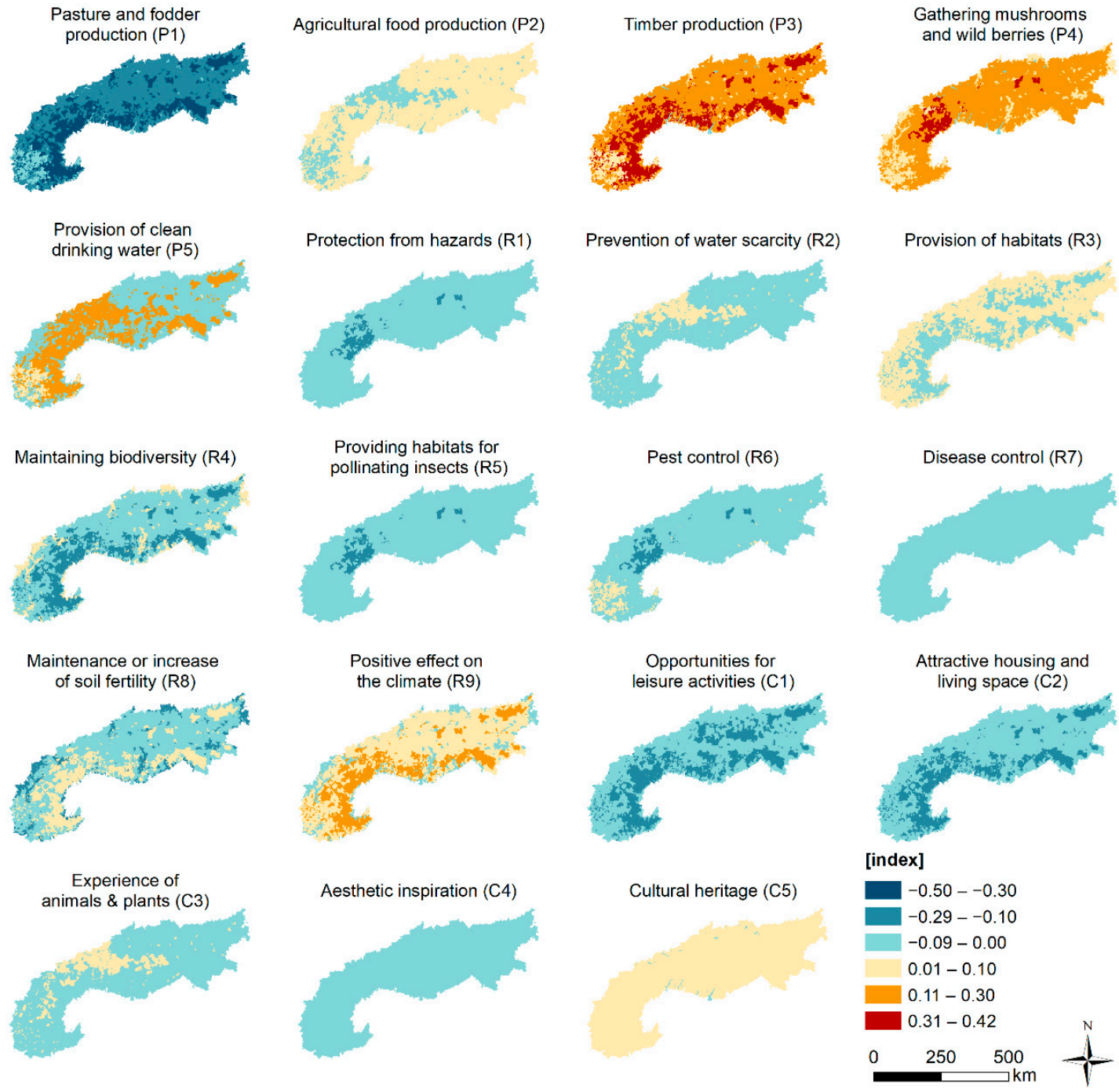

Figure 5. Changes in ES values between 2000 and 2018 across the European Alps. Only agricultural LULC types (crop cultivation, permanent culture, fertilized grassland, unfertilized grassland) that were present in 2000 were considered. Thus, these maps illustrate the changes in agricultural land to other LULC types (including abandoned land, forest, and settlement areas). Authors own elaboration. 


\section{Discussion}

\subsection{Current Trends in Alpine Agricultural Landscapes}

European land management has not been evolving unidirectionally, following predefined trajectories, but rather as path-dependent processes affected by technological, institutional, economic, and social drivers, including sudden events [31]. This is also true for the European Alps [30,31]. Since the beginning of the 20th century, the number of farms in most Alpine regions has decreased by more than $50 \%$, and the share of the population employed in agriculture has decreased from about 70\% to less than 5\% [34], while employment has strongly increased in the secondary, and later in the tertiary, sectors $[34,65]$. Due to unfavorable growing conditions, such as short growing seasons, steep slopes, and small property parcels, which necessitate expensive management practices, while having low productivity, mountain farming cannot compete in national and international markets [31,32,59]. Today, many farmers generate their main income outside their own farm, e.g., in business parks, industrial facilities, shopping centers, and tourism, and the share of part-time farmers is about $70 \%$ in the Alps [61,66]. Therefore, the agricultural area decreased on average by about $20 \%$, and in some areas up to even $70 \%$ [23]. Our results indicate that this trend is still ongoing. The abandoned grassland areas are currently subject to a natural succession process towards site-typical climax vegetation (forest up to the natural timberline, with dwarf shrubs and alpine grassland above) with impacts on ecosystem structure and processes [67]. Our results also indicate that land use has been intensified in favorable locations, mainly through conversion to permanent crops or transformation of agroecosystems into urban or suburban areas. The extent to which these trends will continue depends not only on socio-economic drivers, but increasingly also on climate change. At high altitudes, climate warming will lead to a rise in the timberline, from $300 \mathrm{~m}\left(\right.$ at $\left.+2^{\circ} \mathrm{K}\right)$ to $800 \mathrm{~m}\left(\right.$ at $\left.+5^{\circ} \mathrm{K}\right)$, resulting in a decrease in alpine grassland [67]. However, the temperature increase will cause only a marginal expansion of forested area in $84.3 \%$ of Alpine municipalities, because they do not have areas in the alpine and nival belts [68]. Although climate change does have impacts on land use below $2000 \mathrm{~m}$ a.s.l., economic impacts override climate effects $[59,69]$. As a result of temperature increase and regionally lower precipitation, agricultural use will shift from grassland toward arable farming and permanent crops at lower elevations, whereas grassland farming will intensify at higher elevations [12,59].

Our results indicate that these transformations of agricultural use can jeopardize ES provision and may simultaneously aggravate associated disservices, such as increased leaching of soil nutrients or pests [6,70]. Many ES have declined in recent decades on land formerly used for agriculture, due to the intensification of use or urban sprawl, resulting in LULC types that produce fewer regulating and cultural ES, in particular (see also [25,50]). In addition, some provisioning ES, such as food and fodder production, decreased. In contrast, if forest growth occurs on formerly used grassland (above all in the Italian and Slovenian Alpine regions), timber production will increase, but provision of drinking water (i.e., streamflow) could decrease [71].

\subsection{Implications for Management and Decision-Making}

Our results show that ES values are reduced in most of the selected regions, but with different expressions when divided into provisioning, regulating, and cultural ES. This suggests that increases in ES value can be achieved through targeted regional planning, which also conserves landscape and species diversity, as well as powerful bundles of ES [72]. Moreover, abandoned land can contribute to sustainable land use transitions, providing opportunities to nature-based solutions based on biodiversity, cultural, and regulating services [73]. For management and decision-making, a respective framing must be set to comprehensively evaluate the impacts of agricultural strategies (i.e., on environment and economy). Here, the ES concept should be better integrated into existing frameworks such as the sustainable rural livelihood framework [65]. Moreover, a stronger focus on transdisciplinary research, including the development of adaptive pathways would enable 
stakeholders to translate ES changes into a tangible local or regional agricultural strategy [74]. To highlight the interdependence of different economic sectors and the need for collective action at the local/regional level, to successfully tackle future challenges, the resilience of ES needs to be addressed, in an ecosystem-based approach, in order to duly incorporate the steadily increasing knowledge of changing ecosystem functions and ecosystem processes due to climate change $[57,75]$. This requires a clear commitment to basic research in the field of global change and the use of promising scientific approaches, especially in topographically complex areas, in order to have results available quickly at the landscape level [76,77].

To complete the picture, an appropriate framework must consider the historical development of agricultural strategies, and socio-economic and landscape developments, which means that 'history' must be part of future strategies. Results such as those shown in our study can form the basis and at the same time the starting point for future development paths, which are also increasingly taken up scientifically in landscape ecology, e.g., [40]. However, shifting to more resilient pathways, i.e., developing innovative and adaptive pathways that can mitigate the negative effects of global change on ES [78], can pose significant challenges, especially if land use decisions are predominantly based on agricultural market values. Farmers and decision makers seem to be 'locked-in' to their production-oriented view [40], disregarding the importance of land-use change in promoting other values such as greenhouse gas emissions and sequestration or recreational use and biodiversity [72].

\subsection{Methodological Considerations}

In this study, we applied a simple approach for mapping and quantifying ES values based on LULC maps, which is often applied to generate comprehensive information suitable for decision-making, because it sufficiently accounts for underlying mechanisms and directly illustrates possible impacts from LULC changes $[79,80]$. While this approach is easily replicable, the results contain some uncertainties that need to be considered. One issue regards the LULC types that were used to map ES values, as we differentiated only four types of agricultural use. These are linked to different levels of fertilizer use and have distinct ecological functions and differing species composition [50]. Further levels of fertilization of grassland or differently stocked pastures [12,13], as well as specific types of annual and permanent crops $[55,81]$ could not be distinguished, due to lacking spatial information at a cross-national level. A further refinement could also include a distinction between conventional and organic farming systems for annual crops or permanent cultures [9-11].

There are also limitations with regard to the underlying databases. An updated version of the classification of the eight Alpine regions was not yet available and the classification of some municipalities may have changed, as socio-economic indicators, especially, are less stable than environmental conditions. This may have greater effects on municipalities at low to medium elevations compared to municipalities located higher [82]. Nevertheless, future studies should reclassify the Alpine regions using recent data, which would be particularly important when predicting future agricultural landscapes. Another uncertainty is related to the LULC maps, which originates from methodological issues during the interpretation of different remote sensing data over time, for generating the CLC [83]. To reduce mapping uncertainties, we used the newer versions of CLC. However, in this relatively short time period, only the immediately visible changes from an intensification of use are reflected, while long-term effects such as forest regrowth on abandoned grassland can only be captured over longer monitoring periods $[36,67]$. Over such short periods as in our study, only transitional stages to forest (e.g., heathlands, transitional woodland, shrub) could be considered. In future studies, the results may be improved by differentiating ES values between young and mature forests. Basing our analysis on earlier time steps with a greater extent of agriculturally used land would have revealed greater transformations of agricultural landscapes and related impacts on ES [36,77,84]. 
Furthermore, it has to be noted that our results represent the potential ES supply weighted by socio-cultural preferences, that is, the capacity of ecosystems to provide ES independently of their actual use [80]. However, many studies indicated spatial mismatches between ES supply and ES demand, i.e., the demand exceeds the supply at the local or regional level, requiring the transfer of goods or the movement of people $[19,52,85,86]$. Such dynamics need to be taken into account in the development of sustainable management strategies, and our results should, therefore, be complemented with spatial information on ES demand $[20,24]$.

\section{Conclusions}

By applying the concept of ES, the consequences for society can be assessed in a comprehensive way, highlighting both the direct impacts on agricultural production and the associated effects on regulating and cultural ES. Our results reveal that the agricultural area in the Alpine region is under massive pressure, as up to $30 \%$ of agricultural land in some regions has been abandoned or converted to other uses within the last two decades, despite the efforts made within the framework of the Common Agriculture Policy (CAP) of the European Union (EU). Consequently, ES values mostly declined between 2000 and 2018, especially, regulating and cultural ES, while some forest-related provisioning ES have increased. Our results also indicate that LULC change rates and, hence, changes in ES greatly differed across regions with different social-ecological characteristics. The smallest changes occurred in the traditional agricultural region, while rural retreats and forgotten rural areas were affected by the largest changes.

Such quantitative and spatially explicit information on impacts from the transformation of agricultural land can be used as an information basis for developing sustainable management strategies and for evaluating underlying policies such the CAP. The frequent abandonment of mountain grassland, providing an above-average number of ES, also emphasizes the importance of the Green Deal in the EU, which should be an impulse for an agricultural and food transition. The Green Deal's target of $25 \%$ ecologically valuable farmland in agriculture is one of the central and most important targets, and, therefore, particular attention should be paid to the maintenance of mountain grassland in the European Alps. Finally, to support decision-making in adopting tangible local or regional strategies that can maintain cultural landscapes and multiple ES, greater efforts should be put into transdisciplinary research, allowing for the development of adaptive pathways, depending on the historical development of agricultural use, and socio-economic and landscape developments.

Supplementary Materials: The following are available online at https:/ / www.mdpi.com/article / 10.3390/land11010049/s1, Table S1: Indicators selected for cluster analysis; Table S2: LULC types aggregated from CLC classes; Table S3: ES values (ES supply weighted with socio-cultural preferences) for different LULC types.

Author Contributions: Conceptualization, U.S. and E.T.; methodology, U.S. and E.T.; formal analysis, U.S. and E.T.; writing-original draft preparation, U.S., E.T., G.L. and U.T. All authors have read and agreed to the published version of the manuscript.

Funding: This research received no external funding.

Institutional Review Board Statement: Not applicable.

Informed Consent Statement: Not applicable.

Data Availability Statement: All data used for analysis are publicly available and data sources are indicated. Further information is included in the Supplementary Material.

Conflicts of Interest: The authors declare no conflict of interest. 


\section{Appendix A}
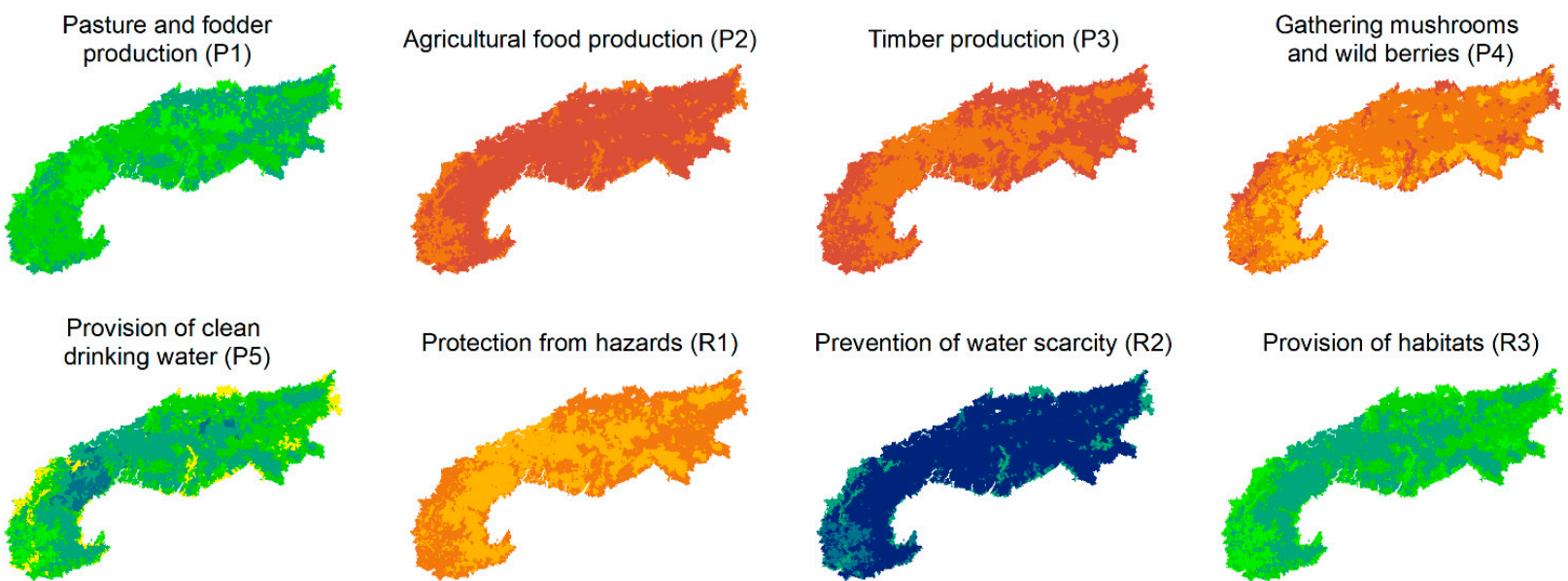

Provision of habitats (R3)

Maintaining biodiversity (R4)
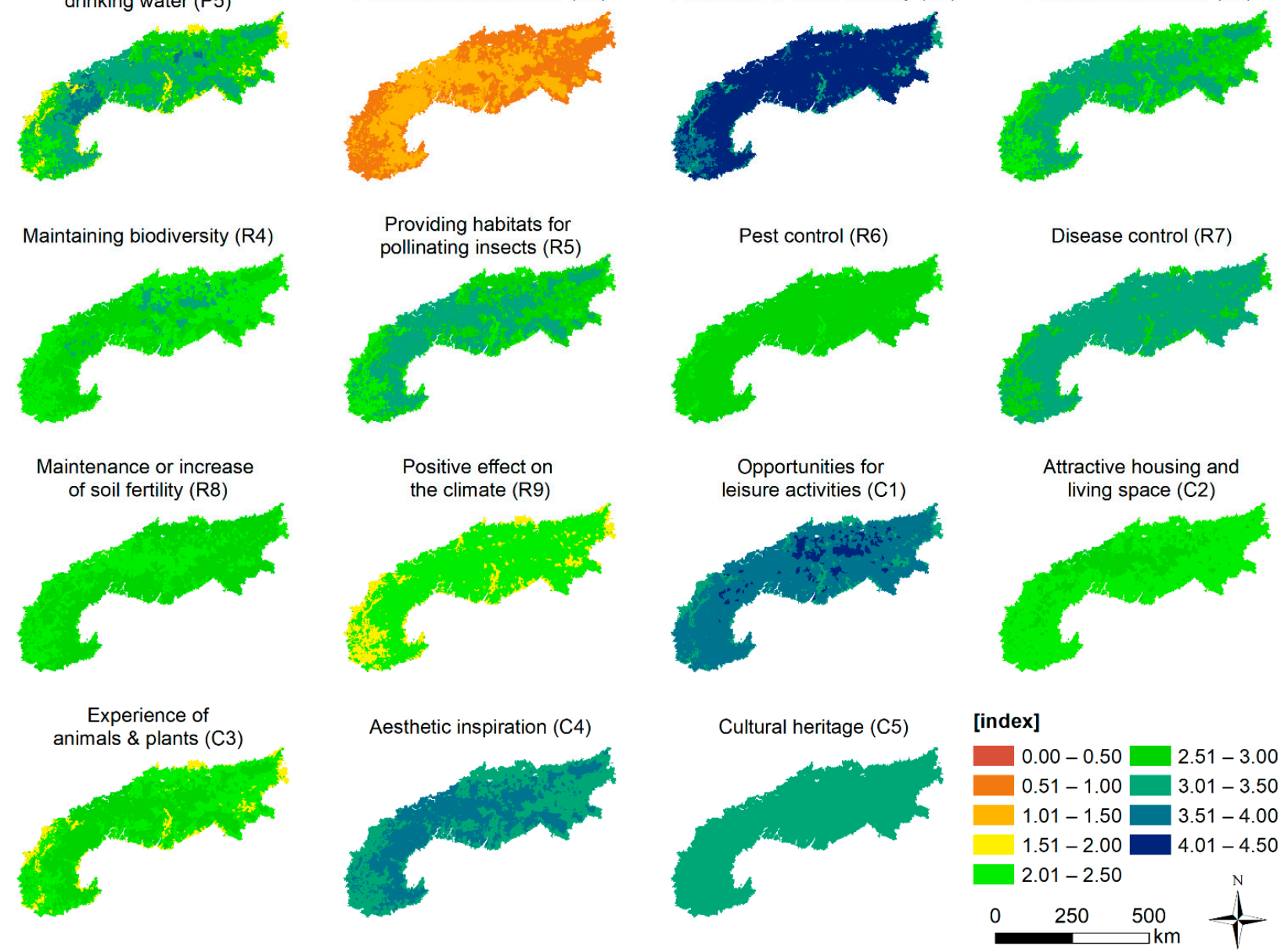

Figure A1. Distribution of ES values in 2018 across the European Alps. Only agricultural LULC types (crop cultivation, permanent culture, fertilized grassland, unfertilized grassland) that were present in 2000 were considered. Thus, these maps illustrate the changes in agricultural land to other LULC types (other agricultural types, abandoned land, forest, settlement areas). Authors own elaboration.

\section{References}

1. Assessment, M.E. Ecosystems and Human Well-Being; Island Press: Washington, DC, USA, 2005; Volume 5.

2. Pascual, U.; Balvanera, P.; Díaz, S.; Pataki, G.; Roth, E.; Stenseke, M.; Watson, R.T.; Başak Dessane, E.; Islar, M.; Kelemen, E.; et al. Valuing nature's contributions to people: The IPBES approach. Curr. Opin. Environ. Sustain. 2017, 26-27, 7-16. [CrossRef]

3. Fuhrer, J.; Smith, P.; Gobiet, A. Implications of climate change scenarios for agriculture in alpine regions-A case study in the Swiss Rhone catchment. Sci. Total Environ. 2014, 493, 1232-1241. [CrossRef] [PubMed]

4. Baude, M.; Meyer, B.C.; Schindewolf, M. Land use change in an agricultural landscape causing degradation of soil based ecosystem services. Sci. Total Environ. 2019, 659, 1526-1536. [CrossRef] [PubMed]

5. García-Llamas, P.; Geijzendorffer, I.R.; García-Nieto, A.P.; Calvo, L.; Suárez-Seoane, S.; Cramer, W. Impact of land cover change on ecosystem service supply in mountain systems: A case study in the Cantabrian Mountains (NW of Spain). Reg. Environ. Chang. 2019, 19, 529-542. [CrossRef] 
6. Zhang, W.; Ricketts, T.H.; Kremen, C.; Carney, K.; Swinton, S.M. Ecosystem services and dis-services to agriculture. Ecol. Econ. 2007, 64, 253-260. [CrossRef]

7. Swinton, S.M.; Lupi, F.; Robertson, G.P.; Hamilton, S.K. Ecosystem services and agriculture: Cultivating agricultural ecosystems for diverse benefits. Ecol. Econ. 2007, 64, 245-252. [CrossRef]

8. Palm, C.; Blanco-Canqui, H.; DeClerck, F.; Gatere, L.; Grace, P. Conservation agriculture and ecosystem services: An overview. Agric. Ecosyst. Environ. 2014, 187, 87-105. [CrossRef]

9. Kremen, C.; Miles, A. Ecosystem Services in Biologically Diversified versus Conventional Farming Systems: Benefits, Externalities, and Trade-Offs. Ecol. Soc. 2012, 17, 40. [CrossRef]

10. Schrama, M.; de Haan, J.J.; Kroonen, M.; Verstegen, H.; Van der Putten, W.H. Crop yield gap and stability in organic and conventional farming systems. Agric. Ecosyst. Environ. 2018, 256, 123-130. [CrossRef]

11. Boone, L.; Roldán-Ruiz, I.; Van Linden, V.; Muylle, H.; Dewulf, J. Environmental sustainability of conventional and organic farming: Accounting for ecosystem services in life cycle assessment. Sci. Total Environ. 2019, 695, 133841. [CrossRef]

12. Jäger, H.; Peratoner, G.; Tappeiner, U.; Tasser, E. Grassland biomass balance in the European Alps: Current and future ecosystem service perspectives. Ecosyst. Serv. 2020, 45, 101163. [CrossRef]

13. Wezel, A.; Stöckli, S.; Tasser, E.; Nitsch, H.; Vincent, A. Good Pastures, Good Meadows: Mountain Farmers' Assessment, Perceptions on Ecosystem Services, and Proposals for Biodiversity Management. Sustainability 2021, 13, 5609. [CrossRef]

14. Troeger-Weiß, G. Die Alpen-Geschichte und Zukunft Einer Europäischen Kulturlandschaft; C.H.Beck: Munich, Germany, 2015; Volume 51, ISBN 9783406681837.

15. Scolozzi, R.; Schirpke, U.; Detassis, C.; Abdullah, S.; Gretter, A. Mapping Alpine Landscape Values and Related Threats as Perceived by Tourists. Landsc. Res. 2015, 40, 451-465. [CrossRef]

16. Schirpke, U.; Meisch, C.; Marsoner, T.; Tappeiner, U. Revealing spatial and temporal patterns of outdoor recreation in the European Alps and their surroundings. Ecosyst. Serv. 2018, 31, 336-350. [CrossRef]

17. Tenerelli, P.; Demšar, U.; Luque, S. Crowdsourcing indicators for cultural ecosystem services: A geographically weighted approach for mountain landscapes. Ecol. Indic. 2016, 64, 237-248. [CrossRef]

18. Zoderer, B.M.; Tasser, E.; Carver, S.; Tappeiner, U. An integrated method for the mapping of landscape preferences at the regional scale. Ecol. Indic. 2019, 106, 105430. [CrossRef]

19. Schirpke, U.; Tappeiner, U.; Tasser, E. A transnational perspective of global and regional ecosystem service flows from and to mountain regions. Sci. Rep. 2019, 9, 6678. [CrossRef]

20. Grêt-Regamey, A.; Weibel, B. Global assessment of mountain ecosystem services using earth observation data. Ecosyst. Serv. 2020, 46, 101213. [CrossRef]

21. Schirpke, U.; Wang, G.; Padoa-Schioppa, E. Editorial: Mountain landscapes: Protected areas, ecosystem services, and future challenges. Ecosyst. Serv. 2021, 49, 101302. [CrossRef]

22. Marini, L.; Klimek, S.; Battisti, A. Mitigating the impacts of the decline of traditional farming on mountain landscapes and biodiversity: A case study in the European Alps. Environ. Sci. Policy 2011, 14, 258-267. [CrossRef]

23. Zimmermann, P.; Tasser, E.; Leitinger, G.; Tappeiner, U. Effects of land-use and land-cover pattern on landscape-scale biodiversity in the European Alps. Agric. Ecosyst. Environ. 2010, 139, 13-22. [CrossRef]

24. Schirpke, U.; Candiago, S.; Egarter Vigl, L.; Jäger, H.; Labadini, A.; Marsoner, T.; Meisch, C.; Tasser, E.; Tappeiner, U. Integrating supply, flow and demand to enhance the understanding of interactions among multiple ecosystem services. Sci. Total Environ. 2019, 651, 928-941. [CrossRef] [PubMed]

25. Schirpke, U.; Tasser, E. Trends in Ecosystem Services across Europe Due to Land-Use/Cover Changes. Sustainability 2021, 13, 7095. [CrossRef]

26. Nadal-Romero, E.; Rubio, P.; Kremyda, V.; Absalah, S.; Cammeraat, E.; Jansen, B.; Lasanta, T. Effects of agricultural land abandonment on soil organic carbon stocks and composition of soil organic matter in the Central Spanish Pyrenees. CATENA 2021, 205, 105441. [CrossRef]

27. Munteanu, C.; Kuemmerle, T.; Boltiziar, M.; Butsic, V.; Gimmi, U.; Halada, L.; Kaim, D.; Király, G.; Konkoly-Gyuró, É.; Kozak, J.; et al. Forest and agricultural land change in the Carpathian region-A meta-analysis of long-term patterns and drivers of change. Land Use Policy 2014, 38, 685-697. [CrossRef]

28. Huber, L.; Schirpke, U.; Marsoner, T.; Tasser, E.; Leitinger, G. Does socioeconomic diversification enhance multifunctionality of mountain landscapes? Ecosyst. Serv. 2020, 44, 101122. [CrossRef]

29. Flury, C.; Huber, R.; Tasser, E. Future of mountain agriculture in the Alps. In The Future of Mountain Agriculture; Springer: Berlin/Heidelberg, Germany, 2013; pp. 105-126. ISBN 9783642335846.

30. Hinojosa, L.; Tasser, E.; Rüdisser, J.; Leitinger, G.; Schermer, M.; Lambin, E.F.; Tappeiner, U. Geographical heterogeneity in mountain grasslands dynamics in the Austrian-Italian Tyrol region. Appl. Geogr. 2019, 106, 50-59. [CrossRef]

31. Jepsen, M.R.; Kuemmerle, T.; Müller, D.; Erb, K.; Verburg, P.H.; Haberl, H.; Vesterager, J.P.; Andrič, M.; Antrop, M.; Austrheim, G.; et al. Transitions in European land-management regimes between 1800 and 2010. Land Use Policy 2015, 49, 53-64. [CrossRef]

32. Dax, T.; Schroll, K.; Machold, I.; Derszniak-Noirjean, M.; Schuh, B.; Gaupp-Berghausen, M. Land Abandonment in Mountain Areas of the EU: An Inevitable Side Effect of Farming Modernization and Neglected Threat to Sustainable Land Use. Land 2021, 10, 591. [CrossRef] 
33. Egarter Vigl, L.; Schirpke, U.; Tasser, E.; Tappeiner, U. Linking long-term landscape dynamics to the multiple interactions among ecosystem services in the European Alps. Landsc. Ecol. 2016, 31, 1903-1918. [CrossRef]

34. Tasser, E.; Schermer, M.; Siegl, G.; Tappeiner, U. Wir Landschaftmacher. Vom Sein und Werden der Kulturlandschaft in Nord-, Ost- und Südtirol; Athesia: Bozen/Bolzano, Italy, 2012; ISBN 8882669068.

35. Schirpke, U.; Zoderer, B.M.; Tappeiner, U.; Tasser, E. Effects of past landscape changes on aesthetic landscape values in the European Alps. Landsc. Urban Plan. 2021, 212, 104109. [CrossRef]

36. Schirpke, U.; Tscholl, S.; Tasser, E. Spatio-temporal changes in ecosystem service values: Effects of land-use changes from past to future (1860-2100). J. Environ. Manag. 2020, 272, 111068. [CrossRef]

37. Egarter Vigl, L.; Marsoner, T.; Schirpke, U.; Tscholl, S.; Candiago, S.; Depellegrin, D. A multi-pressure analysis of ecosystem services for conservation planning in the Alps. Ecosyst. Serv. 2021, 47, 101230. [CrossRef]

38. Stürck, J.; Schulp, C.J.E.; Verburg, P.H. Spatio-temporal dynamics of regulating ecosystem services in Europe- The role of past and future land use change. Appl. Geogr. 2015, 63, 121-135. [CrossRef]

39. Marando, F.; Salvatori, E.; Sebastiani, A.; Fusaro, L.; Manes, F. Regulating Ecosystem Services and Green Infrastructure: Assessment of Urban Heat Island effect mitigation in the municipality of Rome, Italy. Ecol. Modell. 2019, 392, 92-102. [CrossRef]

40. Tappeiner, U.; Leitinger, G.; Zarina, A.; Bürgi, M. How to consider history in landscape ecology: Patterns, processes, and pathways. Landsc. Ecol. 2020, 36, 2317-2328. [CrossRef]

41. Guerry, A.D.; Polasky, S.; Lubchenco, J.; Chaplin-Kramer, R.; Daily, G.C.; Griffin, R.; Ruckelshaus, M.; Bateman, I.J.; Duraiappah, A.; Elmqvist, T.; et al. Natural capital and ecosystem services informing decisions: From promise to practice. Proc. Natl. Acad. Sci. USA 2015, 112, 7348-7355. [CrossRef]

42. Huber, R.; Rigling, A.; Bebi, P.; Brand, F.S.; Briner, S.; Buttler, A.; Elkin, C.; Gillet, F.; Grêt-Regamey, A.; Hirschi, C.; et al Sustainable land use in mountain regions under global change: Synthesis across scales and disciplines. Ecol. Soc. 2013, 18, 36. [CrossRef]

43. Brunner, S.H.; Grêt-Regamey, A. Policy strategies to foster the resilience of mountain social-ecological systems under uncertain global change. Environ. Sci. Policy 2016, 66, 129-139. [CrossRef]

44. Martín-López, B.; Leister, I.; Lorenzo Cruz, P.; Palomo, I.; Grêt-Regamey, A.; Harrison, P.A.; Lavorel, S.; Locatelli, B.; Luque, S.; Walz, A. Nature's contributions to people in mountains: A review. PLoS ONE 2019, 14, e0217847. [CrossRef] [PubMed]

45. McKenzie, E.; Posner, S.; Tillmann, P.; Bernhardt, J.R.; Howard, K.; Rosenthal, A. Understanding the Use of Ecosystem Service Knowledge in Decision Making: Lessons from International Experiences of Spatial Planning. Environ. Plan. C Gov. Policy 2014, 32, 320-340. [CrossRef]

46. Hauck, J.; Görg, C.; Varjopuro, R.; Ratamäki, O.; Maes, J.; Wittmer, H.; Jax, K. “Maps have an air of authority”: Potential benefits and challenges of ecosystem service maps at different levels of decision making. Ecosyst. Serv. 2013, 4, 25-32. [CrossRef]

47. Paprotny, D.; Terefenko, P.; Giza, A.; Czapliński, P.; Vousdoukas, M.I. Future losses of ecosystem services due to coastal erosion in Europe. Sci. Total Environ. 2021, 760, 144310. [CrossRef]

48. Spake, R.; Lasseur, R.; Crouzat, E.; Bullock, J.M.; Lavorel, S.; Parks, K.E.; Schaafsma, M.; Bennett, E.M.; Maes, J.; Mulligan, M.; et al. Unpacking ecosystem service bundles: Towards predictive mapping of synergies and trade-offs between ecosystem services. Glob. Environ. Chang. 2017, 47, 37-50. [CrossRef]

49. Turkelboom, F.; Leone, M.; Jacobs, S.; Kelemen, E.; García-Llorente, M.; Baró, F.; Termansen, M.; Barton, D.N.; Berry, P.; Stange, E.; et al. When we cannot have it all: Ecosystem services trade-offs in the context of spatial planning. Ecosyst. Serv. 2018, 29, 566-578. [CrossRef]

50. Tasser, E.; Schirpke, U.; Zoderer, B.M.; Tappeiner, U. Towards an integrative assessment of land-use type values from the perspective of ecosystem services. Ecosyst. Serv. 2020, 42, 101082. [CrossRef]

51. Geneletti, D.; Scolozzi, R.; Adem Esmail, B. Assessing ecosystem services and biodiversity tradeoffs across agricultural landscapes in a mountain region. Int. J. Biodivers. Sci. Ecosyst. Serv. Manag. 2018, 14, 188-208. [CrossRef]

52. Ala-Hulkko, T.; Kotavaara, O.; Alahuhta, J.; Hjort, J. Mapping supply and demand of a provisioning ecosystem service across Europe. Ecol. Indic. 2019, 103, 520-529. [CrossRef]

53. González-García, A.; Palomo, I.; González, J.A.; López, C.A.; Montes, C. Quantifying spatial supply-demand mismatches in ecosystem services provides insights for land-use planning. Land Use Policy 2020, 94, 104493. [CrossRef]

54. Maes, J.; Egoh, B.; Willemen, L.; Liquete, C.; Vihervaara, P.; Schägner, J.P.; Grizzetti, B.; Drakou, E.G.; La Notte, A.; Zulian, G.; et al. Mapping ecosystem services for policy support and decision making in the European Union. Ecosyst. Serv. 2012, 1, 31-39. [CrossRef]

55. Lasseur, R.; Vannier, C.; Lefebvre, J.; Longaretti, P.-Y.; Lavorel, S. Landscape-scale modeling of agricultural land use for the quantification of ecosystem services. J. Appl. Remote Sens. 2018, 12, 046024. [CrossRef]

56. Mengist, W.; Soromessa, T.; Legese, G. Ecosystem services research in mountainous regions: A systematic literature review on current knowledge and research gaps. Sci. Total Environ. 2020, 702, 134581. [CrossRef] [PubMed]

57. Lavorel, S.; Grigulis, K.; Leitinger, G.; Kohler, M.; Schirpke, U.; Tappeiner, U. Historical trajectories in land use pattern and grassland ecosystem services in two European alpine landscapes. Reg. Environ. Chang. 2017, 17, 2251-2264. [CrossRef] [PubMed]

58. Sauter, I.; Kienast, F.; Bolliger, J.; Winter, B.; Pazúr, R. Changes in demand and supply of ecosystem services under scenarios of future land use in Vorarlberg, Austria. J. Mt. Sci. 2019, 16, 2793-2809. [CrossRef] 
59. Briner, S.; Elkin, C.; Huber, R. Evaluating the relative impact of climate and economic changes on forest and agricultural ecosystem services in mountain regions. J. Environ. Manag. 2013, 129, 414-422. [CrossRef]

60. Grêt-Regamey, A.; Sirén, E.; Brunner, S.H.; Weibel, B. Review of decision support tools to operationalize the ecosystem services concept. Ecosyst. Serv. 2017, 26, 306-315. [CrossRef]

61. Tappeiner, U.; Borsdorf, A.; Tasser, E.I. Alpenatlas: Society, Economy, Environment = Atlas des Alpes = Atlante delle Alpi= Atlas Alp= Mapping the Alps; Spektrum Akademischer Verlag: Heidelberg, Germany, 2008; ISBN 978-3-8274-2004-6.

62. European Environment Agency Corine Land Cover (CLC) 2000, Version 2020_20u1. Available online: https://land.copernicus eu/pan-european/corine-land-cover/clc-2000 (accessed on 26 April 2021).

63. European Environment Agency Corine Land Cover (CLC) 2018, Version 2020_20u1. Available online: https://land.copernicus. eu/pan-european/corine-land-cover/clc2018 (accessed on 26 April 2021).

64. Pecher, C.; Bacher, M.; Tasser, E.; Tappeiner, U. Agricultural landscapes between intensification and abandonment: The expectations of the public in a Central-Alpine cross-border region. Landsc. Res. 2018, 43, 428-442. [CrossRef]

65. Stotten, R.; Ambrosi, L.; Tasser, E.; Leitinger, G. Social-ecological resilience in remote mountain communities: Toward a novel framework for an interdisciplinary investigation. Ecol. Soc. 2021, 26, 29. [CrossRef]

66. Niedermayr, J.; Hoffmann, C.; Stawinoga, A.; Streifeneder, T. Agro-structural patterns in the Alps 2000-2010. Jahrb. Osterr. Ges. Agrar. 2015, 24, 275-284.

67. Tasser, E.; Leitinger, G.; Tappeiner, U. Climate change versus land-use change-What affects the mountain landscapes more? Land Use Policy 2017, 60, 60-72. [CrossRef]

68. Pecher, C.; Tasser, E.; Tappeiner, U. Definition of the potential treeline in the European Alps and its benefit for sustainability monitoring. Ecol. Indic. 2011, 11, 438-447. [CrossRef]

69. Huber, R.; Briner, S.; Bugmann, H.; Elkin, C.; Hirschi, C.; Seidl, R.; Snell, R.; Rigling, A. Inter- and transdisciplinary perspective on the integration of ecological processes into ecosystem services analysis in a mountain region. Ecol. Process. 2014, 3, 9. [CrossRef]

70. Shackleton, C.M.; Ruwanza, S.; Sinasson Sanni, G.K.; Bennett, S.; De Lacy, P.; Modipa, R.; Mtati, N.; Sachikonye, M.; Thondhlana, G. Unpacking Pandora's Box: Understanding and Categorising Ecosystem Disservices for Environmental Management and Human Wellbeing. Ecosystems 2016, 19, 587-600. [CrossRef]

71. Strasser, U.; Förster, K.; Formayer, H.; Hofmeister, F.; Marke, T.; Meißl, G.; Nadeem, I.; Stotten, R.; Schermer, M. Storylines of combined future land use and climate scenarios and their hydrological impacts in an Alpine catchment (Brixental/Austria). Sci. Total Environ. 2019, 657, 746-763. [CrossRef]

72. Bateman, I.J.; Harwood, A.R.; Mace, G.M.; Watson, R.T.; Abson, D.J.; Andrews, B.; Binner, A.; Crowe, A.; Day, B.H.; Dugdale, S.; et al. Bringing ecosystem services into economic decision-making: Land use in the United Kingdom. Science 2013, 341, 45-50. [CrossRef] [PubMed]

73. Fayet, C.M.J.; Reilly, K.H.; Van Ham, C.; Verburg, P.H. What is the future of abandoned agricultural lands? A systematic review of alternative trajectories in Europe. Land Use Policy 2022, 112, 105833. [CrossRef]

74. Schermer, M.; Stotten, R.; Strasser, U.; Meißl, G.; Marke, T.; Förster, K.; Formayer, H. The Role of Transdisciplinary Research for Agricultural Climate Change Adaptation Strategies. Agronomy 2018, 8, 237. [CrossRef]

75. Kohler, M.; Devaux, C.; Grigulis, K.; Leitinger, G.; Lavorel, S.; Tappeiner, U. Plant functional assemblages as indicators of the resilience of grassland ecosystem service provision. Ecol. Indic. 2017, 73, 118-127. [CrossRef]

76. Schirpke, U.; Kohler, M.; Leitinger, G.; Fontana, V.; Tasser, E.; Tappeiner, U. Future impacts of changing land-use and climate on ecosystem services of mountain grassland and their resilience. Ecosyst. Serv. 2017, 26, 79-94. [CrossRef]

77. Schirpke, U.; Leitinger, G.; Tasser, E.; Rüdisser, J.; Fontana, V.; Tappeiner, U. Functional spatial units are fundamental for modelling ecosystem services in mountain regions. Appl. Geogr. 2020, 118, 102200. [CrossRef]

78. Lavorel, S.; Colloff, M.J.; Locatelli, B.; Gorddard, R.; Prober, S.M.; Gabillet, M.; Devaux, C.; Laforgue, D.; Peyrache-Gadeau, V. Mustering the power of ecosystems for adaptation to climate change. Environ. Sci. Policy 2019, 92, 87-97. [CrossRef]

79. Jacobs, S.; Burkhard, B.; Van Daele, T.; Staes, J.; Schneiders, A. 'The Matrix Reloaded': A review of expert knowledge use for mapping ecosystem services. Ecol. Modell. 2015, 295, 21-30. [CrossRef]

80. Burkhard, B.; Kroll, F.; Nedkov, S.; Müller, F. Mapping ecosystem service supply, demand and budgets. Ecol. Indic. 2012, 21, 17-29. [CrossRef]

81. Rega, C.; Short, C.; Pérez-Soba, M.; Luisa Paracchini, M. A classification of European agricultural land using an energy-based intensity indicator and detailed crop description. Landsc. Urban Plan. 2020, 198, 103793. [CrossRef]

82. Hinojosa, L.; Napoléone, C.; Moulery, M.; Lambin, E.F. The "mountain effect" in the abandonment of grasslands: Insights from the French Southern Alps. Agric. Ecosyst. Environ. 2016, 221, 115-124. [CrossRef]

83. García-Álvarez, D.; Camacho Olmedo, M.T. Changes in the methodology used in the production of the Spanish CORINE: Uncertainty analysis of the new maps. Int. J. Appl. Earth Obs. Geoinf. 2017, 63, 55-67. [CrossRef]

84. Locatelli, B.; Lavorel, S.; Sloan, S.; Tappeiner, U.; Geneletti, D. Characteristic trajectories of ecosystem services in mountains. Front. Ecol. Environ. 2017, 15, 150-159. [CrossRef]

85. Serna-Chavez, H.M.; Schulp, C.J.E.; Van Bodegom, P.M.; Bouten, W.; Verburg, P.H.; Davidson, M.D. A quantitative framework for assessing spatial flows of ecosystem services. Ecol. Indic. 2014, 39, 24-33. [CrossRef]

86. Syrbe, R.U.; Grunewald, K. Ecosystem service supply and demand-the challenge to balance spatial mismatches. Int. J. Biodivers. Sci. Ecosyst. Serv. Manag. 2017, 13, 148-161. [CrossRef] 